\title{
Correction to: Mixed methods research: what it is and what it could be
}

Rob Timans ${ }^{1} \cdot$ Paul Wouters $^{2} \cdot$ Johan Heilbron $^{3}$

Published online: 6 May 2019

(C) Springer Nature B.V. 2019

\section{Correction to: Theory and Society (2019) 48:193-216 https://doi.org/10.1007/s11186-019-09345-5}

Unfortunately, figure 2 was incorrectly published. Please find here the correct figure.

The online version of the original article can be found at https://doi.org/10.1007/s11186-019-09345-5

Rob Timans

timans@essb.eur.nl

Paul Wouters

p.f.wouters@cwts.leidenuniv.nl

Johan Heilbron

heilbron@msh-paris.fr

1 Erasmus Centre for Economic Sociology (ECES), Erasmus University Rotterdam, Rotterdam, Netherlands

2 Centre for Science and Technology Studies (CWTS), Leiden University, Leiden, Netherlands

3 Erasmus Centre for Economic Sociology (ECES), Rotterdam and Centre européen de sociologie et de science politique de la Sorbonne (CESSP-CNRS-EHESS), Paris, France 


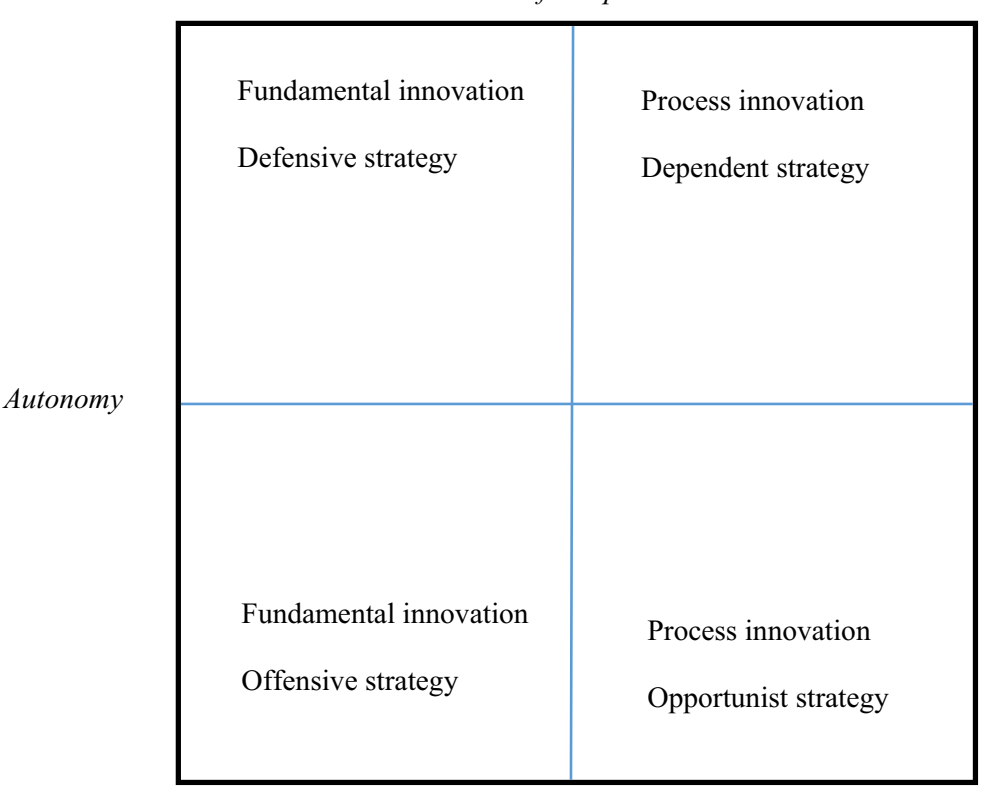

Heteronomy

Scientific capital -

Fig. 2 Scientific field and scientific innovation

Publisher's note Springer Nature remains neutral with regard to jurisdictional claims in published maps and institutional affiliations. 